\title{
Participação social através da criação de um conselho de saúde: relato de experiência
}

\author{
Matheus Laurente Alvarenga, Jéssica Luiza Ripani Rodrigues, Matheus Soares, Raissa Dalat, \\ Roberto Magalhães, Thiago Leister de Medeiros
}

\section{Resumo}

O movimento da reforma sanitária brasileira caminhou ao lado do processo de redemocratização do país, tornando presentes a participação e o controle social na Constituição Brasileira de 1988 e nos planos do então novo Sistema Único de Saúde (SUS). No âmbito da participação popular, a Lei $\mathrm{N}^{\circ}$ 8.142, de 28 de Dezembro de 1990 dispõe sobre a participação da comunidade na gestão do SUS e sobre as transferências intergovernamentais de recursos financeiros na área da saúde. Um dos resultados disso é a garantia da existência dos Conselhos de Saúde pela $\S 2^{\circ}$ da lei 8.142: "O Conselho de Saúde, em caráter permanente e deliberativo, órgão colegiado composto por representantes do governo, prestadores de serviço, profissionais de saúde e usuários, atua na formulação de estratégias e no controle da execução da política de saúde na instância correspondente, inclusive nos aspectos econômicos e financeiros, cujas decisões serão homologadas pelo chefe do poder legalmente constituído em cada esfera do governo". Destaca-se a importância do Conselho Local de Saúde (CLS) nas esferas municipal, estadual e federal como viés da descentralização, atendimento integral e participação social da saúde. Relatar a experiência de auxílio na implementação de um CLS e da conscientização comunitária local a respeito da importância da participação social em sua plenitude. Trata-se de um relato de experiência de membros da Liga Acadêmica de Saúde Coletiva da UFV-LASAC durante atuação no Bairro Bom Jesus, no município de Viçosa-MG. Foram realizadas as seguintes ações: conceituação de CLS e como implementá-lo; estudo do Regimento interno do estatuto do CLS de Nova Viçosa, como base para a criação de um próprio para Bom Jesus; reconhecimento da comunidade e fortalecimento do vínculo com a mesma e sua UBS; elaboração de um plano de ação com base no reconhecimento de fragilidades encontradas na criação de outros conselhos locais, assim como experiências bemsucedidas; reuniões com conselheiros municipais para a melhor compreensão da conjuntura atual; reuniões para a aprovação do estatuto do CLS de Bom Jesus e; elaboração de estratégia de capacitação dos conselheiros com auxílio de professores da Universidade Federal de Viçosa. Houveram diversos avanços na construção do CLS de Bom Jesus durantes os meses de março a julho de 2016, assim como o fortalecimento do vínculo comunidade-conselho, representado pela crescente presença de moradores nas reuniões realizadas nesse período. Pode-se notar que as atividades da LASAC, que envolveram a disseminação do conhecimento e da importância da participação social, fortaleceram e motivaram a comunidade a participar e estar mais ciente da gestão da saúde em sua localidade e município. Além disso foi fortalecido o trabalho interdisciplinar entre acadêmicos e profissionais de diferentes áreas da saúde. É de extrema importância a criação de um conselho local de saúde por proporcionar à população intervenções nas decisões públicas e busca por garantia dos seus direitos. O empoderamento social é a base para conscientização da comunidade quanto à sua participação na gestão em saúde, atingindo assim melhorias para o coletivo.

Descritores: Participação social; Conselhos de saúde; Empoderamento 